\title{
Occupational exposure to contaminated biological material: perceptions and feelings experienced among dental students
}

\author{
Exposição ocupacional a material biológico contaminado: percepções e \\ sentimentos vivenciados entre acadêmicos de Odontologia
}

Camila PINELLI ${ }^{a}$, Luis Felipe Garcia Leal MOUTA ${ }^{a}$

${ }^{a}$ Faculdade de Odontologia, UNESP - Univ Estadual Paulista, Araraquara, SP, Brasil

\begin{abstract}
Resumo
Introdução: Estudantes de Odontologia podem ser particularmente vulneráveis ao risco de adquirir infecções por acidentes de trabalho. Objetivo: Investigar os sentimentos vivenciados entre acadêmicos de Odontologia que sofreram acidentes de trabalho por exposição a material biológico contaminado. Material e método: Entrevistas foram realizadas por meio de um roteiro de perguntas abertas e gravadas. Após a transcrição dos depoimentos, realizou-se a análise qualitativa com auxílio do programa QUALIQUANTISOFT e obteve-se o Discurso do Sujeito Coletivo (DSC). Resultado: Os sentimentos vivenciados pela maioria dos acadêmicos estavam relacionados ao medo de contágio. A maioria dos acidentes ocorreu durante o manuseio do instrumental perfurocortante. Os entrevistados atribuíram a ocorrência dos acidentes principalmente à falta de atenção, descuido durante o manuseio do perfurocortante e à falta de uso de EPIs. Quanto às condutas após a injúria, a primeira medida mais adotada foi "lavar o local da perfuração". Outros entrevistados relataram "continuar o atendimento". A maior queixa foi "medo de ter se contaminado", ou "ter que ir ao hospital para realizar teste rápido para HIV". Como aprendizado, os acidentados afirmaram que passaram a ter mais cuidado ao manusear perfurocortantes. Os acadêmicos relataram que todas as formas de contato com material biológico contaminado devem ser notificadas. Porém foram negligentes ao relatarem sua própria injúria. Conclusão: As medidas educativas de prevenção e segurança no trabalho precisam ser reestruturadas, uma vez que o conhecimento e o medo de contágio entre os estudantes de odontologia nem sempre foram suficientes para a completa adesão aos protocolos de atendimento e de notificação.
\end{abstract}

Descritores: Epidemiologia; estudantes de odontologia; exposição a agentes biológicos; exposição ocupacional; pesquisa qualitativa; saúde do trabalhador.

\begin{abstract}
Introduction: Dental students may be a particularly vulnerable group exposed to the risk of acquiring infections through occupational injuries. Objective: To investigate the perceptions with regard to their occupational exposure to potentially infectious biologic materials. Material and method: Interviews were conducted by means of a script with open questions. The speeches were recorded, transcribed and qualitative analysis was performed with the aid of QUALIQUANTISOFT software. The Collective Subject Discourse (CSD) was obtained. Result: The feeling most frequently experienced was related to the fear of contagion. Most accidents occurred during the handling of sharp dental instruments. Respondents attributed the occurrence of accidents especially the lack of attention, carelessness while handling sharp instruments, and lack of use of Personal Protective Equipment. As regards the measures taken right after the exposure, they "washed the local area". Other respondents reported they "continued the dental treatment". They complained mostly about the fear of having been infected, and because they had to leave the faculty to take blood exams for HIV screening. As part of the learning experience the injured reported they paid more attention when handling sharp instruments. The students informed that any type of injury due to contact with contaminated material must be notified. However, they were neglectful about reporting their own injury. Conclusion: Education strategies for preventive measures related to occupational exposure must be restructured, because the knowledge and the fear of contagion among dental students were not always sufficient for a complete adherence to treatment protocols and notification.
\end{abstract}

Descriptors: Epidemiology; students dental; exposure to biological agents; occupational exposure; qualitative research; occupational health. 


\section{INTRODUCTION}

By definition, injuries sustained by perforating sharps involve any type ranging from contact with non intact skin, ocular mucosa, mucosal membrane or parenteral contact (laceration or puncture with a needle or other sharp instrument), through to blood or other potentially infectious material (saliva) - which occurs during the diagnosis and treatment of a patient, or when dealing with unclean oral impressions, prosthetic appliances and during the disposition of needs or other sharp instruments ${ }^{1,2}$.

The occupational risk of acquiring an infection by exposure to contaminated biologic material is real, and depends on the extension of the lesion, volume of fluid, system conditions of the accident victim, characteristics of the microorganisms present, clinical condition of the source-patient, and post-exposure procedures performed ${ }^{3}$. Although the risk of transmission of the HIV virus is lower than the risk of transmission of Hepatitis B and $\mathrm{C}$, occupational acquisition of HIV represents a serious consequence of accidents involving perforating sharps ${ }^{1,4}$, in addition to the fact that the pathogens mentioned may have a long period of incubation and many workers may be carriers without knowing it ${ }^{5}$.

Work accidents involving perforating sharps are more frequent among dental students than among dentists ${ }^{1,6-8}$, a fact attributed to the lower level of manual dexterity of students. A previous study ${ }^{1}$ verified that occupational skills are an important factor in the occurrence of injuries by perforating sharps, because dental students suffered twice as many injuries when compared with dentists with over 10 years of experience.

In Brazil, there is relatively little information with respect to the frequency and nature of accidents resulting from occupational exposure to contaminated biologic material, or about the consequences resulting from these injuries ${ }^{5}$. One of the reasons is the under-notification of cases among students and health professionals ${ }^{9}$, either because of the inconvenience and fear that the accident report may cause, or because of lack of knowledge about the need for notification of the accident, or disbelief of the importance and severity of a work accident of this nature ${ }^{10}$. It is estimated that $50 \%$ of accidents due to perforating sharps are not notified ${ }^{11}$.

However, health professionals have the duty to protect themselves, their colleagues and patients from possible contaminations ${ }^{12}$ and the under-notification of accidents is an important limiting factor from the preventionalist point of view ${ }^{10}$. In addition to the injury itself, the work accident with biologic material may represent losses not only for the accident victim, but to society as a whole, either by his/her own suffering and that of his/her family, or by the financial costs involved in treatment. Therefore, the analysis of accidents must involve a broad and organizational systemic approach ${ }^{13}$.

International researches have been conducted to seek to know the rates of exposure among dental and medical students ${ }^{6,7,14,15}$. A high rate of under-notification of accidents with exposure to bloodborne pathogens was verified, with a difference in accident report rate between 3rd (35\%) and 4th Year (14.5\%) Dentistry undergraduates ${ }^{15}$.

The aim of the present study was to identify the feelings experienced and the post-accident procedures performed among dental students who suffered accident with contaminated biologic material.

\section{MATERIAL AND METHOD}

This was a descriptive research with a qualitative approach, among students who had had accidents with biologic material in the year 2012, in a School of Dentistry at a Public University in the State of São Paulo.

In view of the characteristics of the study - considering undergraduate dental students as subjects, and the dental care environment as the locality of actions - the feelings experienced after occupational exposure and the post-accident procedures performed were investigated. A total of 25 volunteers participated in the research.

The interviews were held in a room providing the participants with complete privacy. A semi-structured interview script was used with 10 questions. The statements were recorded and the audio content was transcribed on paper/computer, keeping faithfully to that which was reported.

For the study of the perceptions of the research subjects the proposal of Lefèvre, Lefèvre ${ }^{16}$ was used, denominated the Analysis of Collective Subject Discourse (CSD). This proposal is carried out by means of quali-quantitative analysis. With the aid of the QUALIQUANTISOFT ${ }^{\oplus}$ software program, which uses three methodological figures - central-ideas, key-expressions and the CSD itself - the statements were evaluated.

For construction of the CSD, in depth reading of the individual speeches was carried out, resulting in the interpretation of each of the questions. After this, the significant contents were associated (key-expressions - KEXs), present in each discursive construction of each subject, with the respective central-ideas (CIs). The CIs, understood as methodological figures, allowed translation of the essential matter of the speeches made by the subjects in their statements, which were synthetized in categories, in order to express all the ideas in the same sense. Finally the respective KEXs were aggregated in order to form a coherent discursive whole.

With regard to the ethical aspects of the research involving human beings, the Research Ethics Committee of the local institution approved the project (CAAE - 0005.0.199.000-11) and the participants were asked to sign a specific Term of Free and Informed Consent before the interviews were held.

\section{RESULT}

For presentation of the qualitative results, the suggestion of Lefèvre, Lefèvre ${ }^{16}$ of preparing a synthesis chart (Chart 1), containing each question of the proposed script, as well as the respective categories was followed. 
Chart 1. Synthesis of the CSD and categories, according to the central ideas of 25 volunteers

Question 1 - Have you ever had any accident with contaminated biologic material from the patient?

Category A: Yes, a splash or contact with aerosol. (20\%)

Category B: Yes, while washing material. (20\%)

Category C: Yes, when handing dental instruments. (60\%)

Question 2 - How did you feel at this time?

Category A: Nervous. (12\%)

Category B: Calm. (20\%)

Category C: I felt afraid of a contamination. (60\%)

Category D: I was in doubt about going to talk to the professor. (4\%)

Category E: I felt frustrated. (4\%)

Question 3 - In your opinion, which factor contributed to your accident with biologic material?

Category A: Lack and incorrect use of IPEs. (20\%)

Category B: Lack of attention/carelessness $(68 \%)$

Category C: Hurry (12\%)

Question 4 - What was the first measure you took after the accident?

Category A: I washed my eyes. (16\%)

Category B: I washed the perforation site. (56\%)

Category C: I sought the professor. (24\%)

Category D: I concluded the procedure and informed the professor. (4\%)

Question 5 - And after this, what did you do?

Category A: Continued with the procedure. (52\%)

Category B: Sought care at the health clinic. (44\%)

Category C: I only filled out the documentation. (4\%)

Question 6 - Did you receive any help at the time of the accident?

Category A: I did not receive help. (44\%)

Category B: Yes. I did. (48\%)

Category C: I did not ask for help. (8\%)

Question 7 - What was the worst or most difficult aspect to deal with after you had the accident?

Category A: The worry about a possible contamination. ( $60 \%)$

Category B: Going to the hospital. (16\%)

Category C: The anxiety about the results. (8\%)

Category D: About the source-patient. (4\%)

Category E: Nothing difficult. (8\%)

Category F: Not having received help at the time. (4\%)

Question 8 - What is the result of your experience, with the fact that you were contaminated with biologic material?

Category A: I use more protection. (12\%)

Category B: I began to be more careful. (88\%)

Question 9 - Among the forms of contact with contaminated biologic material, which of these must be informed to the medical service?

Category A: All forms of contact. (52\%)

Category B: Cuts and perforations. (24\%)

Category C: Contact with blood and saliva. (24\%)

Question 10 - Did you notify your accident with biologic material? Why?

Category A: I did not notify. (52\%)

Category B: I notified, because of the worry. (36\%)

Category C: I notified, because it is the protocol of the school. (12\%) 


\section{DISCUSSION}

For the majority of the interviewees, at the time of the accident, feelings of despair and fear of contamination prevailed:

I felt complete despair, and I was very afraid that I was contaminated. I was very scared that the patient had some serious illness and had contaminated me. In the beginning I was very worried, tense at the time, but afterwards I tried to calm myself, because I talked to the professor and calmed down. The patient had cancer. There was no blood or anything, but I was worried. At the time I though the patient had some infectious contagious disease like AIDS or Hepatitis.

This social representation about accidents with biologic material is very frequent among various health professionals. A previous study verified that the biologic risk generated fear and anguish among professionals whether they had suffered accidents or not ${ }^{17}$. The literature shows that in the first moment, the attentions are centered on a possible contamination with HIV, HVB and $\mathrm{HVC}$ viruses ${ }^{18}$.

However, it drew attention to the fact that over half of the interviewees did not notify their own accident. The reasons pointed out for non-notification were perception of the low risk of contamination - because they knew the patient, or because it was a child - and the perception that care in the reference unit took a long time:

I did not notify, because the procedure was performed in a child and I thought it unnecessary at the time. It was a very small cut [...]. I also thought it was very little for me to worry about. Even the professor advised me that it was not necessary to make a notification or even have exams done. [...] It was late and I ended up trusting my patient who told me he/she had no disease [...]. Apart from this, we know the bureaucracy that goes on at the small healthcare clinic, and I would be there for hours. At the time I thought I wasn't contaminated and I didn't worry.

These results are in agreement with the literature, seeing that there have been low rates of notification of the occurrence of accidents with biologic material ${ }^{2,18}$.

The under-notification of accidents prevents that the present teaching Institution knows the true dimension of occurrences, making it difficult to plan and develop accident prevention and control actions ${ }^{19}$.

With regard to the first measure implemented right after the accident the following was observed: "cleaning the exposed area", and "find the professor instructor to be able to notify". One may note an incorrect belief that enzymatic soap must be used for hand washing, in which participants made reference to the use of "degerming soap", instead of "enzymatic detergent". Another product that was frequently related for use on the skin was alcohol. The social representation that alcohol acts as a wound disinfectant is an incorrect belief, because the immediate care after percutaneous lesions is summed up in exhaustive washing of the exposed site with water and soap. In exposures that attain the mucosal tissues, the recommendation is to wash exhaustively with water or physiological solution ${ }^{4,6}$.

When evaluating the interviewees' responses with regard to Question 5, analysis of the discourses showed that half of them $(n=13)$ continued caring for the patient and these were confirmed as being the same individuals who did not notify the accident. However, one has to consider that the fact that they did not notify did not always indicate complete negligence with regard to the accident they suffered, because the discourses showed that many of them sought the professor in charge to talk about what should be done. Thus the lack of notification was related to other judgments, such as confidence in the opinion of the professor in charge that the accident in question did not represent threats, or the belief that the individual would be safe because of having observed the clinical chart and anamnesis of the sourcepatient. Therefore, many of these students who were accident victims decided on continuing with caring for the patient and not registering the notification.

I was not in contact with anything, at most - saliva. I did not do anything, only continued with the procedure. I talked to the professor and talked to my patient, we went to consult the patients chart to see if it related any health problem, and as the patient was someone known to us, we saw that there was no problem. My professor put me at ease [...], I put on new gloves and carried on with what I was doing.

Although the literature shows that work accidents with blood and oral fluids trigger a process of reflex-action in exposed workers, leading to a profound view of their understanding with respect to work accidents ${ }^{18}$, there are other individuals who play down the severity of such accidents, because they are not really aware of the risks involved ${ }^{9}$. This disdain can be observed in the present study, in situations such as a small cut reported, having confidence in the source-patient's anamnesis, or the fact of the patient being a child.

Considering the apparent disregard of the risk to which they are exposed, it is necessary to establish strategies of awareness and education among dental students and the entire community of docents and course tutors, so that they may attribute greater weight to the undesirable consequences that the accident of exposure to biologic material may cause. There is no vaccine against HIV, and AIDS is a disease that continues to be a challenge to public health, with 37 thousand new cases per annum in Brazil, of which 7 thousand occur in the State of São Paulo ${ }^{20}$. Recent studies have shown that the AIDS virus has undergone mutations ${ }^{21}$. The diagnostic tests - especially the fast tests used in the first hours after the accident - would need to be more sensitive and specific to trace the contemporary genetic diversity.

With regard to the fact of having received some help at the time of the accident, approximately half the students interviewed felt satisfied:

I was helped by a friend and the staff of the clinic. The professor also helped me a great deal, accompanied me to the health clinic, to the social assistant. More help came from my working partner. I also received help from a post-graduate student, who instructed me to perform all the necessary procedures, including talking to the professor, who performed all the procedures correctly. The person who accompanied me to the hospital was a post-graduate student. I received all the assistance I needed.

However, 12 interviewees complained about the lack of help, in terms of resoluteness in the face of the post-accident procedures:

I received no help whatever. Only a professor who calmed me down, but did nothing. I had no help from anyone. 
The need for taking care of students who are accident victims and knowledge about the stages of post-accident care are divulged in the protocols of the institution and available in posters in the teaching clinics, in the form of a Standard Operating Procedures (SOP). This indicates the need to motivate the instructors frequently, to increase the notification rate, especially for situations involving perforating sharps.

As regards the type of material involved in the accident, the majority of reports indicated the perforating sharps, as may be seen in the following discourse:

It was an Endodontic instrument, a bur in truth, it was engaged at low speed [...] the tip pierced my arm. I turned to get the low speed motor and ended up perforating myself, the bur fell onto my foot. [...] When I went to uncap the needle for irrigation, I ended up punching my finger [...]. I punctured myself with a suture needle, during suturing. My partner threw the needle into my hands and I ended up pricking myself. I was removing my patient's ties with an exploratory probe. In truth, my assistant left the anesthesia needle uncapped and I didn't see. In truth the material was to blame, it was very thin [...] they are very sharp.

These results are in agreement with the literature ${ }^{22}$, which indicates that the most frequent type of accident involving contaminated biologic material, is of the perforating sharps type and occurs during clinical attendance. The parts of the body most frequently subject to accidents are the hands and fingers ${ }^{23}$. Another time when it was common for injury to occur was during instrument cleaning ${ }^{24}$.

Considering the causes of the accidents, the reports of interviewees attributed blame to individual failures, such as distraction, carelessness, hurry to finish up to go, and failure to use PPE (Personal Protective Equipment). This result showed the predominance among students at this Institution of the culture that the accident is attributed to the individual level:

I confess that I was in a hurry to go. I was without an assistant, attending alone and it was a little late and I needed to dismiss the patient. I had a second patient on the day, so I went to wash my material, and forgot to put on thick gloves to get on with it more quickly, and ended up perforating hand.

\section{Or:}

Carelessness on my part. I didn't take care to take the cutter out after I had finished using it. Lack of attention at the time of the procedure. It was my mistake, I did something wrong, I shouldn't have put the needle into the pot. Great lack of attention at the time I washed my material, I became distracted by persons. I took my material incorrectly, I shouldn't have picked it up like that. Much distraction on my part, in truth it was carelessness. I wasn't using closed shoes or stockings, that is why it happened, I was wearing open shoes.

The lack of preparation when judging the accident as an individual error is very common among health workers. This approach is inadequate and indicates the need for implementing measures of systematic evaluation of work processes, among the various teaching environments of the school, for the management of risk control, as foreseen by the Ministry of Labor and Employment ${ }^{13}$.

With the interest in going more deeply into the knowledge of the cause of the accidents here related by means of the present qualitative research, the researches visited some of the teaching clinics, during different times, and over the course of a month, recorded the different situations that interfered in the students' safety, as regards the possible causes of exposure to contaminated biologic material.

Firstly, in the cleaning area it could be verified that more trays for transporting contaminated material between the clinical and cleaning area are necessary, because some students had the habit of carrying the perforating sharps in their hands, indicating the risk of falling or accidents due to bumping into someone/ something.

Another situation analyzed indicated problems with the dimension of the physical area of the cleaning area, because it was crowded, exceeding the limit of up to 6 persons. Therefore, during the final minutes before leaving the clinic, before lunch and at the end of the afternoon, the cleaning area was inadequate for the number of students who wished to wash their materials, all at the same time. As the students themselves did not respect the maximum limit of the number of users in the cleaning area, there is a need to program follow-up measure, education and supervision of the activity.

Another very common situation with the neglect to use PPEs, or closed shoes, in which the students manipulated contaminated material in the cleaning area without using thick gloves, protective goggles and wearing open shoes. As regards discarding anesthesia needles, there was predominance of using fingers to activate and unscrew the needle from the metal of the carpule-type syringe in order to discard it afterwards. This activity, qualified as being incorrect, must be performed with the use of safety devices, such as hemostatic forceps or needle holders. This portion shows the lack of PPE use:

Yes, I was dealing with an emergency and aerosol sprayed into my eyes. I was also performing a restoration when drops of saliva went flying [...]. Another time, I was performing prophylaxis when saliva fell into myeyes.

The literature shows that lack or inadequate use of PPEs implies the more frequent occurrence of accidents ${ }^{8,9}$. The preventive measures in Dentistry involves working practices based on the use of PPEs, and particularly training and qualification in risk management. According to the literature, the question of the increase in the use of PPE must mainly be education, motivation and supervision, and not the availability of the equipment ${ }^{25}$.

On the other hand, considering the change in attitudes, there was greater adhesion to the use of PPE, especially protective goggles, in order to prevent new accidents:

I am more cautious, I correctly use PPEs, particularly protective goggles, irrespective of the patient being an adult or child. I know I need to be better equipped, irrespective of the procedure. I am a great deal more concerned about using PPEs now and about covering all the parts that may be contaminated.

As regards the difficulties in relating the accident, the interviewees pointed out:

Having to go to the hospital alone was more difficult, because no one went with me. All the bureaucracy itself of the perforating sharps accident, particularly having to go out to go to hospital. No one likes going out to go to another place, especially to have blood collected. The doubt about having to go to SESA or UPA, this is more difficult.

(Note: SESA refers to Special Service of Health, and UPA refers to Emergency Unit). 
The anxiety of waiting for the results was another factor observed as being more difficult to deal with after the accident. The exposure itself and waiting for the results of serological exams may cause important emotional shock ${ }^{4}$. The fear of possibly having a disease and not knowing, in addition to the time waiting for results that take about a month to be ready worried the interviewees who notified their accidents

Anxiety due to waiting for the results. In the beginning I was very frightened because of not knowing whether I was contaminated, but afterwards the anxiety about the results, because it takes a long time for them to be ready.

Other students did not find anything difficult, because the fully trusted the patient's clinical chart, or due to the fact that they had not suffered perforation. According to the literature, the individuals in the health area tend to consider accidents with biologic materials somewhat routine, and become indifferent to the risk of contamination ${ }^{26}$.

As a result of the experience of having suffered an accident with contaminated biologic material, the majority of the volunteers reported that they are paying more attention during clinical procedures and when cleaning instruments:

It was good, because it was an experience that showed I don't need to despair and now it if happens again, I know what to do. I am always going to be more careful with the instruments we use. I began to be more careful during my procedures, and pay a lot more attention. My attention has tripled now, I take a lot of care not to perforate myself. I pay much more attention now at the time of washing my things. This is very dangerous, one suffers an affliction because of not knowing what the person has, so one begins to pay much more attention to things. We also need to take the maximum amount of care possible, even with protective goggles I felt that drops flew into my eyes. From the beginning to the end of my attendance I will pay more attention. I am much more careful with what I do now and it's not likely to happen again. I learned that I cannot be in a hurry, the greater the hurry, the worse it is, it is the enemy of perfection. I have learned to handle instruments better. I started wearing thick stockings and closed shoes to the clinics.

With regard to knowledge about the forms of contact with biological material of the patient, which must be notified to the medical service, the majority of the interviewees revealed that they thought it valid to notify all types:

I believe that there is a risk of transmitting disease in all forms of biologic material. I believe that all, irrespective of whether there was contact with blood and saliva in a perforation, I think that if something got into your eye, the medical service must be informed. It is valid to notify all forms of contact. I think it's good that any means of contamination should be informed. Irrespective of the biologic material, but I think there is more risk with some than with others.

In order for the accident prevention program to be effective, all operating processes proposed by the Ministry of Labor and Employment ${ }^{13}$ serve as guidelines for the institutionalization of a safety culture in the work environment, implementation of procedures for registration and investigation of accidents and risk situations, among other procedures.

It is worth considering that the teaching strategies and prevention need to be reformulated in order to act on the change in paradigm among the academic community, in search of greater uniformization to help to make the work environment safer.

\section{CONCLUSION}

The fear of contamination was the feeling most observed. On the other hand, the majority of interviewees did not notify the accident because they considered it unnecessary to do so. This inconsistency between the feeling of fear of contagion and lack of notification of accidents may be related to the organizational aspects of the teaching institution here investigated. It is worth pointing out that in order to educate an individual within a culture of biosafety and infection control, it is necessary to go beyond the current form, which occurs in a diffused manner in the curricular grid, because there is no discipline specifically focused on this type of training. It is necessary to avoid opinions that are frequently contradictory among professors themselves who discourage the notification of accidents, whether it is because of the belief that the injury was small, or because it involves transportation of the accident victim, source-patient and the professor in charge to a unit of reference. One has to consider that the students interviewed attributed the cause of accidents to aspects circumscribed by themselves - under the individual's own responsibility, instead of to a broad and systemic view with regard to the work environment. The need was detected for sharing the safety culture in the work environment, which although institutionalized at this school, still encounters obstacles. The training of the entire community represents a new challenge to be overcome, in order to increase the awareness of the students and professors of the importance of notification of injuries, and in order to program processes to evaluate the improvement in performance of post-accident procedures.

\section{REFERENCES}

1. Wicker S, Rabenau HF. Occupational exposures to bloodborne viruses among German dental professionals and students in a clinical setting. Int Arch Occup Environ Health. 2010; 83(1): 77-83. PMid:19626335. http://dx.doi.org/10.1007/s00420-009-0452-3

2. Brozoski MA, Traina AA, Naclério-Homem MG, Deboni MCZ. Ocorrência de acidentes pérfuro-cortantes em um Curso de Odontologia. RGO - Rev Gaúcha Odontol. 2010; 58(1): 77-80.

3. Machado Carvalhais HP, Martins TCPM, Ramos-Jorge ML, Magela-Machado L, Paiva SM, Pordeus IA. Management of occupational bloodborne exposure in a dental teaching environment. J Dent Educ. 2007; 71(10): 1348-55. PMid:17923713.

4. Garcia LP, Blank VLG. Condutas pós-exposição ocupacional a material biológico na odontologia. Rev Saúde Pública. 2008; 42(2): 279-86. http://dx.doi.org/10.1590/S0034-89102008000200013

5. Garcia LP, Blank VLG. Prevalência de exposições ocupacionais de cirurgiões-dentistas e auxiliares de consultório dentário a material biológico. Cad Saúde Pública. 2006; 22 (2): 97-108. PMid:16470287. 
6. Ramoz-Gomez F, Ellison J, Greenspan D, Bird W, Lowe S, Gerberding JL. Accidental exposures to bloodborne and body fluids among healthcare workers in dental teaching clinics: a prospective study. J Am Dent Assoc. 1997; 128(9): 1253-61. http://dx.doi.org/10.14219/ jada.archive.1997.0402

7. Wood AJ, Nadershahi NA, Fredekind RE, Cuny EJ, Chambers DW. Student occupational exposure incidence: perception versus reality. J Dent Educ. 2006; 70(10): 1081-8. PMid:17021288.

8. Machado Carvalhais HP, Ramos-Jorge ML, Auad SM, Martins LHPM, Paiva SM, Pordeus IA. Occupational exposure to potentially infectious biological material in a dental teaching environment. J Dent Educ. 2008; 72(10): 1201-8. PMid:18923101.

9. Damasceno AP, Pereira MS, Silva e Souza AC, Tipple AFV, Prado MA. Acidentes ocupacionais com material biológico: a percepção do profissional acidentado. Rev Bras Enferm. 2006; 59(1): 72-7. http://dx.doi.org/10.1590/S0034-71672006000100014

10. Napoleão AA, Robazzi MLCC, Marziale MHP. Causas de subnotificação de acidentes do trabalho entre trabalhadores de enfermagem. Rev Latino-Am Enfermagem. 2000; 8: 119-20. http://dx.doi.org/10.1590/S0104-11692000000300018

11. Harris SA, Nicolai LA. Ocupational exposures in emergency medical service providers and knowledge of and compliance with universal precautions. Am J Infect Control. 2010; 38(2): 86-94. PMid:19815310. http://dx.doi.org/10.1016/j.ajic.2009.05.012

12. Van Gemert-Pijnen J, Hendrix MGR, van der Palen J, Schellens PJ. Effectiveness of protocols for preventing occupational exposure to blood and body in Dutch hospitals. J Hosp Infec. 2006; 62(3): 166-73. PMid:16257086. http://dx.doi.org/10.1016/j.jhin.2005.07.010

13. Rapparini C, Reinhardt EL. Manual de implementação: programa de prevenção de acidentes com materiais perfurocortantes em serviços de saúde. São Paulo: Fundacentro; 2010.

14. Stewardson DA, Burke FJ, Elkhazindar MM, McHugh ES, Mellor AC, Coulter WA, et al. The incidence of occupational exposures among students in four UK dental schools. Int Dent J. 2004; 54(1): 26-32. http://dx.doi.org/10.1111/j.1875-595X.2004.tb00249.x

15. Kotelchuck D, Murphy D, Younai F. Impact of underreporting on the management of occupational bloodborne exposures in a dental teaching environment. J Dent Educ. 2004; 68(6): 614-22. PMid:15217080.

16. Lefèvre F, Lefèvre AMC. O discurso do sujeito coletivo. Um novo enfoque em pesquisa qualitativa (desdobramentos). Caxias do Sul: EDUCS; 2003.

17. Murofuse TN, Ignácio Alves DC, Fávero GC, Brotto AO. Comportamento dos acadêmicos, docentes e técnicos-administrativos da clínica Odontológica da Unioeste: riscos ocupacionais e atividades desenvolvidas. Acta Sci Health Sci. 2008; 30(1): 81-7. http://dx.doi. org/10.4025/actascihealthsci.v30i1.587

18. Sarquis LMM, Felli VEA. Os sentimentos vivenciados após exposição ocupacional entre trabalhadores de saúde: fulcro para repensar o trabalho em instituições de saúde. Rev Bras Enferm. 2009; 62(5): 701-4. http://dx.doi.org/10.1590/S0034-71672009000500008

19. Ribeiro AS, Bgabataz RIB, Neves ET, Padoin SMM. Caracterização de Acidente com Material Perfurocortante e a percepção da equipe de enfermagem. Cogitare Enfermagem. 2009; 14(4): 660-6.

20. Fioravanti C. Aids ainda longe do controle. Pesquisa FAPESP. 2012 out (200): 63-7.

21. Sanabani SS, Pessôa R, Soares de Oliveira AC, Martinez VP, Giret MT, de Menezes Succi RC, et al. Variability of HIV-1 genomes among children and adolescents from São Paulo, Brazil. Plos One; 2013; 8(5): e625-52. PMid:23667488 PMCid:PMC3646872. http://dx.doi. org/10.1371/journal.pone.0062552

22. Orestes-Cardoso SM, Farias ALF, Pereira MRMG, Orestes-Cardoso AJ, Cunha Júnior IF.Acidentes perfurocortantes: prevalência e medidas profiláticas em alunos de odontologia. Rev Bras Saúde Ocup. 2009; 34(119): 6-14. http://dx.doi.org/10.1590/S0303-76572009000100002

23. Nascimento LS, Assunção LR, Silva Junior NG, Pedreira EM, Silva RLC. Acidentes com pérfuro-cortantes na Faculdade de Odontologia da UFPA: visualização de um cenário. ROBRAC: Rev Odontol Bras Central. 2012; 21(57): 463-7.

24. Cruz, ACC, Gasparetto A. Ocorrência de acidentes com instrumentos pérfuro-cortantes em alunos de graduação do curso de Odontologia da Universidade Paranaense. Arq Ci Saúde UNIPAR. 1999; 3 (3): 199-203.

25. Toledo Júnior AC, Ribeiro FA, Ferreira FGF, Ferraz RM, Greco DB. Conhecimento, atitudes e comportamentos frente ao risco ocupacional de exposição ao HIV entre estudantes de Medicina da Faculdade de Medicina da Universidade Federal de Minas Gerais. Rev Soc Bras Med Trop. 1999; 32(5): 509-15. http://dx.doi.org/10.1590/S0037-86821999000500007

26. Figueiredo RM, Garcia MT, Resende MR, Papaiordana PMO. Acidentes com risco biológico: a adesão de profissionais de saúde ao seguimento. Anais do 51 ${ }^{\circ}$ Congresso Brasileiro de Enfermagem e $10^{\circ}$ Congresso Panamericano de Enfermagem; 1999 out 2-7; Florianópolis, BR. Florianópolis: ABEn; 2000. p. 358.

\section{CONFLICTS OF INTEREST}

The authors declare no conflicts of interest.

\section{CORRESPONDING AUTHOR}

Camila Pinelli

Departamento de Odontologia Social, Faculdade de Odontologia de Araraquara, UNESP - Univ Estadual Paulista, Rua

Humaitá, 1680, 14801-903 Araraquara - SP, Brasil

e-mail: cpinelli@foar.unesp.br 